\title{
Pop Music Rivalry in Indonesia: Past, Present and Future Trends
}

\author{
Harriman Samuel Saragih \\ Business School - Management Department \\ Universitas Pelita Harapan \\ Tangerang, Indonesia \\ harriman.saragih@uph.edu
}

\begin{abstract}
Popular music in Indonesia have shown significant evolution and transformations from the 90's up until the present day. We studied the 1990's renaissance which devised idiosyncratic and typical styles compared to the 2000's and ultimately the 2010's. As the 21st century enables the society to stream music from countless parts of the world, indeed Indonesian music artists do not only compete with the domestic musicians, but also with the musical groups from overseas countries. This study will provide preliminary analysis, insights and facts regarding the trends of popular music from the three eras, to be the basis for predicting the future trends in 2020's. In the end, this study is expected to contribute insights for academicians, business practitioners and musicians to forecast the future trend, to be able to endure unremittingly in the vastly dynamics popular music market in Indonesia.
\end{abstract}

\section{Keywords - pop music; trend; indonesia; rivalry; forecast}

\section{INTRODUCTION}

Amongst musical genres, popular music is the most listened music category in Indonesia. Before continuing, the definition of popular music on this study shall first be determined. Several explanations regarding popular music were gathered, for example music written and marketed with the intention of achieving mass distribution and sales now principally in the form of recordings [1]; music having wide appeal, characterized by lightly romantic or sentimental melodies [2]; music appealing to the popular taste, including rock and pop and also soul, reggae, rap, and dance music [3]. Hereafter, on this paper pop music is defined as the category of music which is marketed massively, embedded with the local taste, have wide appeal, which mostly characterized by lightly romantic or sentimental melodies. This study also limit that the popular music scope is Indonesian popular music, delivered by Indonesian artists and usually combines Bahasa Indonesia and English.

In order to support this definition, several most prominent popular pop music artists in Indonesia ranging from the 1980's, 1990's, 2000's, to 2010's are studied and presented. Rolling Stone Indonesia, as the leading magazine in music entertainment, have formerly listed these prominent and irreplaceable musicians in the respective era entitled "25 Artis Indonesia Terbesar Sepanjang Masa" [4]. Naming a few 'oldies' artists on the early 80's to early 90's era which Indonesian modern citizen must be familiar with for instance Achmad Albar, Bimbo, Titiek Puspa, Koes Plus, Guruh Soekarno Putra, Chrisye, Iwan Fals. Newly born artists in the 90's such as Padi, Sheila on 7, Dewa 19, Slank, Kahitna, Ungu,
Glenn Fredly. Finally, in the $21^{\text {st }}$ century, in the millennium era we have Peterpan, Raisa Andriana, Tulus, Isyana Sarasvati, Judika, RAN, Kerispatih. These artists are known due to their popular songs that are widely spread and listened in Indonesian cities.

There are plentiful of popular music studies in Indonesia, however those that collect information of popular music in multiple eras ranging from 1980's to 2010's is still lacking. Therefore, this study aims to expound the historical development of popular music in terms of a number of aspects. We will use several parameters in order to narrow the scope of the patterns and characteristics of popular music. These parameters will later be the basis of suggesting future development of Indonesian pop music. Aspects examined in this study are type of artist (Band, solo, vocal group, etc.), characteristic of the song, and marketing distribution (physical album, digital album, live concert, radio, etc.).

Previous studies regarding the prediction for upcoming trends in the field of popular music, particularly in Indonesia, have been lacking. Before forecasting the future trends, an exploration to the historical development of popular music is presented. In order to explicate general understanding regarding the popular music history from the 80's to the present date, three aspects will be reviewed and presented on this section which comprises of technological revolution, business model alterations, and the pop songs characteristics that shown similar pattern in the last thirty years. Cross-case analysis is used in this study to distill these characteristics and patterns of popular music through different eras. The result will further be suggested as the basis to forecast future trend of popular music

\section{LITERATURE REVIEW}

\section{A. Technology}

Technology is radically shifting the forms of societal relations among the artist and the listeners. It is since technology be able to evaluate each of the components of a given motion and then reform them. As musical performances become reformed through technology, these communal relations evaporate as well as the artistic meanings related with them. Consequently, a technological aesthetics of music is progressing [5]. In general, the music industry landscape has shown radical changes in the past thirty years. From cassettes, CD's, MP3's, and AAC's digital downloads provided by iTunes [6]. This study argues that the revolution started since the birth of the MP3, July 1994 [7]. Generally, the music industry had been showing 
substantial decline in terms of revenue and growth [8]. The rise of the internet is assumed as the main factor that drive the music industry into the present state. Internet and MP3 have driven the current music industry globally, where people can stream music without costs anytime and anywhere they like [9]. Consequently, the importance of acknowledging the effect of technological advance on the music industry shall be the main point of record companies [9].

\section{B. Business Model}

The landscape of music business has also been changing since the technological alteration. Record companies and music artists must actively explore new ways of finding revenue generators for their music. Physical album marketing was effective only until the birth of MP3; which since then, the mixture of Internet and MP3 have deteriorated the old method. Online music technology, such as MP3 and AAC formats are the beginning of a new age of technology, which without doubt will significantly affect music industry [9]. The major companies have sought to adapt to the challenges of software formats and Internet distribution systems through litigation, diversifying through multimedia, seeking to add new revenue streams (such as ring tones and merchandising) while promoting transparency so that people can see the value added by labels in the networks of the musical economy [8].

The major companies have sought to adapt to the challenges of software formats and Internet distribution systems through litigation, diversifying through multimedia, seeking to add new revenue streams (such as ring tones and merchandising) while promoting transparency so that people can see the value added by labels in the networks of the musical economy [8]. Different business models, for example those introduced by On-line Music and Music-Broker, sees to reformulate the musical economy by re-intermediating musical value chains. This contains efforts to profoundly reconfigure opportunities within the industry, such as challenging the concept of the 'album', or a 'single' to be more efficient and effective in the market.

Since music sharing had become very common, buying music in form of physical such as CD's or cassettes is now not anymore become an option. Music artists in developed and developing countries often renovate some business models to persist. The innovation comprises of finding new artists, new revenue stream, and new marketing and distribution strategy [10]. We can obviously see that the problems in the music industry is indeed because the traditional business model of physical album was falling and revenues also profits declined rapidly. $C D$ sales had been decreasing significantly, while alternate formats for music distribution such as iTunes have grown more important. We can eventually say that in this present day, the 'old' business model is no longer functioning - while it is still also unclear regarding how the 'new' business model will be - in terms of effectivity and efficiency [11]. Koster (2011) mentioned that after almost ten years of turmoil, some trends appear in the music industry as a whole, but do not yet see very specific business models: continuous steep declines of CD sales, partly compensated by increasing digital sales; profusion of different models for digital music revenues; aggressive moves of concert promoters into the recording business and the webcasting of concerts; moves of labels into the concert business; fusion of the two main components of the music industry [12].

\section{Characteristics}

Several earlier studies that examined the characteristics of pop songs are collected. Tagg (1982) argues that popular music cannot be analyzed using only the traditional tools of musicology since popular music, is conceived for mass distribution to large and often socio-culturally heterogeneous groups of listeners; stored and distributed in non-written form; only possible in an industrial monetary economy where it becomes a commodity and; in capitalist society, subject to the laws of 'free' enterprise, according to which it should ideally sell as much as possible of as little as possible to as many as possible [13].

Even though Tagg (1982) argued with such statements, formerly, Boyle (1981) examined students' preferences in popular music. He compared responses of students in grades five, seven, nine, eleven, and college, as well as responses of students with different experience and background characteristics. Results exposed that characteristics such as the melody, mood, rhythm, and lyrics of a selection were the most important reasons for preference. Sociocultural variables generally were viewed as less important [14].

Popular music has also been linked to engaged directly with the youth consumers due to its everydayness, the ways in which it is woven into everyday life and is often insignificant and mundane [15]. Popular culture often doesn't have to mean anything but can be handy to pass the time, to fill a silence or to entertain in rather banal ways. I would argue that popular music is sometimes meaningful, in certain instances, but not always [15]. Hence, popular music is still able to be characterized. In this study, pop music characteristics will adapt some of the pop music traits studied by Boyle (1981).

\section{Adopt, Absorb, Innovate}

Dynamic capability [16] was intended in the beginning as a set of ideas to help explicate scope economies, flexibility, adaptability, integration, and disintegration. The contemporary focus on changing technology has spurred increasing focus on organizational change and how environments and the histories of business firms shape organizational forms, practices, and competencies. The dynamic capabilities framework is offered as a guide to the understanding of complex business organizations and contemporary management practices in high performing enterprise [17].

The building blocks of dynamic capability [16] consists of adaptive, absorptive, and innovative capability [18]. Firms must continually adapt with the emerging industry environment, absorb new ways of generating revenues, and also actively engaged in crafting innovation. Specifically, this study argues that every stakeholder - primarily artists and record companies - must contemplate vigorously in order to find the ways to continue producing music as the music landscape in Indonesia have shown vibrant changes in the past ten years.

Studies regarding how dynamic capability framework been used in various industries were gathered. Studies have shown that dynamic capability has assisted firms and companies in surviving the business environment in their respective 
industries. For instance, in industries such as typesetter [19], automobiles and mainframes [20], food [21], semiconductor [22], and hospitality [23]. However, research that examine the role of dynamic capability in creative industry, particularly in music industry has been lacking. Nevertheless, with former analysis of how dynamic capability help firms to strive in the rapid business environment - with adaptive, absorptive, and innovative capacity as the moderating role - this study applies this theoretical groundwork for future recommendations for artists and music firms to endure in the emerging music industry.

This study argues that dynamic capability can also be used in the creative industry, which focus on the talent development of the artists [24]. One of the example regarding how the music industry had been changing is that albums are distributed not only in the music stores, but also in minimarkets, gas station, fast food restaurants [10]. Henceforth, understanding dynamic capability for those doing the music business is crucial with the aim of finding most effective business model. It is highly vital for firms to understand the aspect of dynamic capability so that they can assess and reconstruct its business model which fit with the existing market environment, particularly in the music industry.

\section{ANALYSIS}

\section{A. Technological Revolution}

It is crystal clear that technology - the internet predominantly - have completely changed the music business landscape. Physical album distribution through cassettes and CD's does not effectively become the main revenue generator as in the early 1980's. In Indonesia, two of the most remarkable music stores have stopped their business operations which are Aquarius [25] and Disc Tarra [26]. They have changed their strategies to online music selling as their primary channel. This study firmly believes that their strategic intention to stop distributing physical album is not without any reason. This momentous occurrence is supported by the previous study [27] that music consumers' have shifted their behavior from buying physical albums - mainly in the 1908's to the 1990's era - to digital download or streaming in the present circumstances. Consumers can directly browse and stream through YouTube, Spotify, iTunes, and other music streaming medias. In fact, consumers massively tend to explore music through these digital platforms before they continued to purchase the songs or albums [28].

Radio, on the other hand, is also proposed to be one of the most effective distribution channel of popular music which focuses on broadcasting trending singles to the society. Consumers targeted by radio in this study are mainly teenagers and young adult in the age of 17 to 30 . Singles - compared to whole albums - can generate significant relevance and greatly attract music listeners' and consumers as it distributed through radio and streaming services. Songs from artists such as Raisa, Rizky Febian, Afgan, Peterpan, Kerispatih, were frequently played through the radio, available in online streaming services which then resulted in rapid increase of popularity. One example that support this argument is Rizky Febian's song of Kesempurnaan Cinta that was first published on August $11^{\text {th }}$ 2015 in YouTube, and within ten months it has resulted total of
28 million views [29] which roughly equivalent with 93.000 views per day.

\section{B. Characteristics}

This section will explore the characteristics of popular music in different eras. Characteristics on this study are categorized by its group (e.g. solo, band, or vocal group), mood (e.g. relaxing, enjoyable, energizing, melancholic), song theme (e.g. love, broken-hearted, daily life situations, protests, nationalism) and lyrics (e.g. poetics, rhyme, story-telling). This study only exploits limited samples from various artists, hence it might not generalize and contribute to the complete big picture of the industry at that time. However, these samples are representative as not only the Rolling Stone Magazine evaluation that is used in this study, also the author's point of view and also author's rigorous discussion with numerous musicians and music listeners in Indonesia.

In exploring the characteristics of prominence pop music artists in the 80's to 90's era, reliable literature resources are lacking. Nevertheless, Rolling Stone Indonesia online magazine - which is the most reliable magazine in the field of Indonesian music - has discussed and ranked the popular artists according to some of traits such as their popularity, sales, productivity, and market penetration. Koes Plus, Iwan Fals, Chrisye, Slank, and Dewa 19 on this study are proposed to be the most valuable artists on the respective era [4]. This study does not able to track the amount of sales, total download, or total streaming views of these artists due to limited resource availability. Without doubt, these artists have been widely known in Indonesian music industry in the particular era even until the present day. Top tracks for these artists are summarized on the Table.

\begin{tabular}{|c|c|c|}
\hline Artist & Top Tracks & $\begin{array}{l}\text { Mood, Theme and } \\
\text { Lyrics }\end{array}$ \\
\hline $\begin{array}{l}\text { Koes Plus } \\
\text { Type: Group } \\
\text { Band }\end{array}$ & $\begin{array}{l}\text { Andaikan Kau Datang, Kisah } \\
\text { Sedih Dihari Minggu, Why Do } \\
\text { You Love Me, Bujangan, } \\
\text { Kapan-Kapan, Bunga Ditepi } \\
\text { Jalan, Kembali Ke Djakarta, } \\
\text { Muda-Mudi, Hidup Jang Sepi }\end{array}$ & $\begin{array}{l}\text { Mood: Enjoyable, } \\
\text { Melancholic, } \\
\text { Relaxing } \\
\text { Theme: Love, } \\
\text { broken-hearted, daily } \\
\text { lives } \\
\text { Lyrics: poetic, story- } \\
\text { telling }\end{array}$ \\
\hline $\begin{array}{l}\text { Slank } \\
\text { Type: Group } \\
\text { Band }\end{array}$ & $\begin{array}{l}\text { Terlalu Manis, Ku Tak Bisa, } \\
\text { Anyer } 10 \text { Maret, Kamu Harus } \\
\text { Pulang, Virus, Orkes Sakit Hati, } \\
\text { Mawar Merah, } \\
\text { I Miss You but I Hate You, } \\
\text { Maafkan, Balikin, }\end{array}$ & $\begin{array}{l}\text { Mood: Energizing, } \\
\text { Enjoyable } \\
\text { Theme: Love, daily } \\
\text { lives } \\
\text { Lyrics: story-telling }\end{array}$ \\
\hline $\begin{array}{l}\text { Iwan Fals } \\
\text { Type: Solo }\end{array}$ & $\begin{array}{l}\text { Yang_Terlupakan, Ibu, } \\
\text { Bongkar, Bento, Ijinkan Aku } \\
\text { Menyayangimu, Ujung Aspal } \\
\text { Pondok Gede, Kemesraan, Aku } \\
\text { Bukan Pilihan, Sarjana Muda, } \\
\text { Buku Ini Aku Pinjam }\end{array}$ & $\begin{array}{l}\text { Mood: Energizing, } \\
\text { Melancholic } \\
\text { Theme: Love, Protest } \\
\text { Lyrics: Poetic, story- } \\
\text { telling }\end{array}$ \\
\hline $\begin{array}{l}\text { Chrisye } \\
\text { Type: Solo }\end{array}$ & $\begin{array}{l}\text { Cintaku, Seperti Yang Kau } \\
\text { Minta, Pergilah Kasih, Ketika } \\
\text { Tangan Dan Kaki Berkata, } \\
\text { Andai Aku Bisa, Damai } \\
\text { Bersamamu, Kisah Kasih di } \\
\text { Sekolah, Kala Cinta Menggoda, } \\
\text { Kisah Cintaku }\end{array}$ & $\begin{array}{l}\text { Mood: Enjoyable, } \\
\text { Melancholic } \\
\text { Theme: Love, } \\
\text { Broken-Hearted, } \\
\text { Lyrics: Poetic }\end{array}$ \\
\hline $\begin{array}{l}\text { Dewa } 19 \\
\text { Type: Group } \\
\text { Band }\end{array}$ & $\begin{array}{l}\text { Cinta Gila, Kangen, Pupus, } \\
\text { Risalah Hati, Separuh Nafas, } \\
\text { Takkan Ada Cinta Yang Lain, } \\
\text { Cinta 'kan Membawamu } \\
\text { Kembali, Kamulah Satu- }\end{array}$ & $\begin{array}{l}\text { Mood: Energizing, } \\
\text { Melancholic } \\
\text { Theme: Love, } \\
\text { Broken-Hearted, } \\
\text { Melancholic }\end{array}$ \\
\hline
\end{tabular}


Table 1 Various Former Prominent Indonesian Popular Music Artists

\begin{tabular}{|l|l|l|}
\hline Artist & Top Tracks & $\begin{array}{l}\text { Mood, Theme and } \\
\text { Lyrics }\end{array}$ \\
\hline & $\begin{array}{l}\text { satunya, Roman Picisan, } \\
\text { Kirana }\end{array}$ & Lyrics: Poetic \\
\hline
\end{tabular}

We used YouTube to illustrate the popularity of these remarkable popular music artists according to the total video clip views. Table 2 demonstrates the artist, its popular songs, and total cumulative views based on the popular songs listed. Artists shown in Table X are mainly those active in the 2000's to 2016.

Table 2 Various Modern Indonesian Popular Music Artists in

\begin{tabular}{|c|c|c|c|}
\hline Artist & Popular Songs & $\begin{array}{l}\text { Mood, Theme } \\
\text { and Lyrics }\end{array}$ & $\begin{array}{l}\text { Total } \\
\text { Views }\end{array}$ \\
\hline $\begin{array}{l}\text { Peterpan } \\
\text { Type: } \\
\text { Group } \\
\text { Band }\end{array}$ & $\begin{array}{l}\text { Kukatakan dengan Indah, } \\
\text { Semua Tentang Kita, } \\
\text { Yang Terdalam, } \\
\text { Menghapus Jejakmu, } \\
\text { Mungkin Nanti, Langit } \\
\text { tak Mendengar, Bintang } \\
\text { di Surga, Menunggumu }\end{array}$ & $\begin{array}{l}\text { Mood: } \\
\text { Enjoyable, } \\
\text { Melancholic } \\
\text { Theme: Love, } \\
\text { Broken-hearted } \\
\text { Lyrics: Poetic }\end{array}$ & 40.486 .816 \\
\hline $\begin{array}{l}\text { Sheila on } 7 \\
\text { Type: } \\
\text { Group } \\
\text { Band }\end{array}$ & $\begin{array}{l}\text { Dan, Pemuja Rahasia, } \\
\text { Lapang Dada, Mudah } \\
\text { Saja, Seberapa Pantas, } \\
\text { Hari Bersamanya, } \\
\text { Sahabat Sejati, Itu Aku, } \\
\text { Kita, Yang Terlewatkan, } \\
\text { Berhenti Berharap }\end{array}$ & $\begin{array}{l}\text { Mood: } \\
\text { Enjoyable, } \\
\text { Melancholic, } \\
\text { Energizing } \\
\text { Theme: Love, } \\
\text { broken-hearted } \\
\text { Lyrics: Poetic, } \\
\text { story-telling }\end{array}$ & 52.704 .405 \\
\hline $\begin{array}{l}\text { Raisa } \\
\text { Andriana } \\
\text { Type: Solo }\end{array}$ & $\begin{array}{l}\text { Jatuh Hati, LDR, } \\
\text { Pemeran Hati, Terjebak } \\
\text { Nostalgia, Apalah (Arti } \\
\text { Menunggu), Could It Be, } \\
\text { Serba Salah }\end{array}$ & $\begin{array}{l}\text { Mood: } \\
\text { Melancholic, } \\
\text { Enjoyable } \\
\text { Theme: Love, } \\
\text { Broken-hearted } \\
\text { Lyrics: Poetic, } \\
\text { story-telling }\end{array}$ & 48.267 .755 \\
\hline $\begin{array}{l}\text { Tulus } \\
\text { Type: Solo }\end{array}$ & $\begin{array}{l}\text { Pamit, Teman Hidup, } \\
\text { Sewindu, Sepatu, Baru, } \\
\text { Gajah }\end{array}$ & $\begin{array}{l}\text { Mood: } \\
\text { Enjoyable, } \\
\text { Relaxing } \\
\text { Theme: Love, } \\
\text { Metaphors } \\
\text { Lyrics: Poetic, } \\
\text { story-telling }\end{array}$ & 45.345 .316 \\
\hline $\begin{array}{l}\text { Isyana } \\
\text { Sarasvati } \\
\text { Type: Solo }\end{array}$ & $\begin{array}{l}\text { Kau Adalah, Tetap Dalam } \\
\text { Jiwa }\end{array}$ & $\begin{array}{l}\text { Mood: } \\
\text { Relaxing, } \\
\text { Enjoyable } \\
\text { Theme: Love } \\
\text { Lyrics: Story- } \\
\text { telling }\end{array}$ & 63.151 .229 \\
\hline
\end{tabular}

According to the above analysis of how Indonesian popular music had been evolving in the past thirty years, similar patterns are gathered. Those determine the popularity level in each era have their unique type of group, mood, theme, and lyrics. As previously been discussed, this study focuses on the trend that emerged in the past, present, and predicting the future. Period of the past era is between 1980's to 2000's, present era of 2000's to 2016, while future era is on the 2020's. This grouping is determined due to some revolutionary changes in a particular period - when MP3 was first produced, it was around 1996 to 1997, and my analysis argues that in the early 2000's - within three years after MP3 launched - the music industry landscape changed globally. Table 3 summarizes the unique characteristics on the past and present era. Prediction on the future era will be discussed individually by the basis of the past and present era.
Table 3 Characteristics of Indonesian Pop Music in Several Eras

\begin{tabular}{|l|l|}
\hline Period & Characteristics \\
\hline 1980 's - 2000 & $\begin{array}{l}\text { Type of Groups: Solo, vocal group, group bands. } \\
\text { Mood: Enjoyable, Melancholic, Energizing } \\
\text { Theme: Love, broken-hearted, daily lives, politics, } \\
\text { parents, friendships } \\
\text { Lyrics: Poetic, story-telling }\end{array}$ \\
\hline 2000 's - 2010 & $\begin{array}{l}\text { Type of Groups: Group band, solo } \\
\text { Mood: Enjoyable, Melancholic, Energizing } \\
\text { Theme: Love, broken-hearted } \\
\text { Lyrics: Poetic, story-telling }\end{array}$ \\
\hline 2010 's - 2016 & $\begin{array}{l}\text { Type of Groups: Solo } \\
\text { Mood: Enjoyable, Melancholic } \\
\text { Theme: Love, broken-hearted } \\
\text { Lyrics: Poetic, story-telling }\end{array}$ \\
\hline
\end{tabular}

Each characteristics summary drawn on Table $\mathrm{X}$ is based on generalizing the samples of which these samples represent the most valuable artists in each respective era. It can be seen from Table $X$ that during the last thirty years, Indonesian popular music has shown identical characteristics according to the mood, theme, and lyrics while it also addresses slight changes in the type of group. We will first discuss the mood, theme, and lyrics which later ends with examining the type of groups.

It is without doubt that popular music is first characterized by its enjoy-ability. In the 1980's to the 2000, people can still enjoy music through varying theme from relationship, brokenhearted, parents, politics, and daily lives. Musicians could express their musicality towards different areas of theme. Artists were still able to explore creativities, as the music industry were still supported by physical albums selling and music televisions. In this particular era, group bands and solos were also very famous in the Western music industry. This popularity also affected the Indonesian music from the producers and also listeners.

Nevertheless, in modern Indonesian music market enjoyability is insufficient. Pop songs also need to 'touch' the heart of the listeners, while also easy to be remembered. 'Touching' the heart means the song need to be directly connected with the present situation of its listeners. As we have already discussed in previous section, pop music listeners are those teenagers to young adults - of which, the main problem of these type of consumers is indeed relationships. In Indonesia, the culture of 'galau' is well known (galau in Indonesia means being highly melancholic due to relationships problem). In Indonesian pop music market, popular songs can also be identified as 'lagu galau' or a truly melancholic song. This unique characterization is because most of the teenagers and young adults, tend to sing this melancholic song to express their feelings through the song. This particular idiosyncratic of ' $g a l a u$ ' is not that popular in the past era. Surely, in the past era the specific pop music consumers might also had the same problem with present situation, but this 'galau' term has already been an epidemic culture through the present teenagers and young adults compared to the past - which make love and broken-hearted theme very popular in the present market.

Type of group have shown significant changes in the observed period. Before the early 2000's, physical album sales were still become the primary source of revenue for music producers. By the time the MP3 changed the landscape of the music industry, music producers gradually needed to adapt with 
the changing market situation. Group bands inevitably needed higher revenues and higher costs of producing rather than solos. Therefore, in contrasts the past and the present era, extreme changes were observed: from group bands to solos, as solos can generate higher efficiency compared to a group of people in one band. This study argues that the TV industry had also doomed group bands - either consciously or unconsciously - through 'instant' lip-sync performance of group bands in the early 2000's which make the real performance of the group band is not seen as the primary quality. Hence, more soloist artists born, and with higher efficiency, instant popularity, and how the television industry shaped the image of a group band, soloist are becoming more popular in the present day.

Nonetheless, we can clearly see that the pattern over the last thirty years regarding the theme and the lyric is amongst love and broken-hearted, presented with - mostly poetic -and storytelling lyric; while also enjoyable and often very much melancholic. Meanwhile, type of group predicted in this industry is more soloist in the future due to higher efficiency, easier to develop. If the TV industry remains presenting music bands with present quality of lip-sync, music bands will still become underdogs in Indonesian pop music industry.

For marketing distribution, the patterns can easily be seen. First, there was physical albums which comprises of cassettes and CD's, while secondly, consumers shift to the internet services to stream for music, and specifically in Indonesian market, radio also have important role in marketing pop music artists. There are various internet streaming services, however, this study argues that YouTube, iTunes, and Spotify are the most effective medium to distribute music to Indonesian society, while still, artists and producers shall cooperate with popular radio stations in Indonesia to regularly playback their music in the radio as this also considered highly powerful in marketing popular music to teenagers and young adults.

\section{CONCLUSION}

Technology and cultures indeed play important role in the development of popular music in Indonesia. From physical album to digital downloads, from wide-range of expressions, to focus on love and broken-heart. Popular music in Indonesia has shown consistent pattern in terms of mood, melody, and lyrics while the type of musical group has shown considerable changes due to revolutionary changes in music industry landscape. Based on the review on past events on music market, this study also contributes to forecast the trend of Indonesian popular music in the 2020 .

This study is not without any limitation. Samples on this study only represent few of Indonesian pop artists. This study also categorizes the pop music on limited aspects. Also, further studies are need to determine how to craft the most effective and efficient marketing strategy in Indonesian market. Hence, a clearer image to respond to the music industry in the 2020 can be illustrated with additional focus on this Indonesian music industry.

\section{REFERENCES}

[1] Dictionary.com, ed, 2016.

[2] Merriam Webster Dictionary, ed, 2016.
[3] Oxford Dictionaries, ed, 2016.

[4] Rolling Stone Indonesia. (2015) 25 Artis Indonesia Terbesar Sepanjang Masa. Rollingstone Indonesia. Available: http://www.rollingstone.co.id/article/read/2015/11/23/ 140505071/81/25-indra-lesmana-

[5] J. Frederickson, "Technology and music performance in the age of mechanical reproduction," International Review of the Aesthetics and Sociology of Music, pp. 193-220, 1989.

[6] B. Slade, "Music vs. Technology: Creating a New Industry for the Digital Age," 2011.

[7] J. Denegri-Knott and M. Tadajewski, "The emergence of MP3 technology," Journal of Historical Research in Marketing, vol. 2, pp. 397-425, 2010.

[8] A. Leyshon, P. Webb, S. French, N. Thrift, and L. Crewe, "On the reproduction of the musical economy after the Internet," Media, Culture \& Society, vol. 27, pp. 177209, 2005.

[9] K. Blanchette, "Effects of MP3 Technology on the Music Industry: An Examination of Market Structure and Apple iTunes," College of the Holy Cross. Retrieved September, vol. 30, p. 2004, 2004.

[10] D. Dellyana and T. M. Simatupang, "The 5th Indonesia International Conference on Innovation, Entrepreneurship, and Small Business (IICIES 2013)Existing Music Business Model in Indonesia in Search of New Income Sources," Procedia - Social and Behavioral Sciences, vol. 115, pp. 407-414, 2014/02/21 2014.

[11] H. Chesbrough, "Business model innovation: opportunities and barriers," Long range planning, vol. 43, pp. 354-363, 2010.

[12] A. Koster, "The emerging music business model: back to the future?," Journal of Business Case Studies (JBCS), vol. 4, pp. 17-22, 2011.

[13] P. Tagg, "Analysing popular music: theory, method and practice," Popular music, vol. 2, pp. 37-67, 1982.

[14] J. D. Boyle, G. L. Hosterman, and D. S. Ramsey, "Factors influencing pop music preferences of young people," Journal of Research in Music Education, vol. 29, pp. 47-55, 1981.

[15] C. Williams, "Does it Really Matter? Young People and Popular Music," Popular Music, vol. 20, pp. 223242, 2001.

[16] D. J. Teece, G. Pisano, and A. Shuen, "Dynamic Capabilities and Strategic Management," Strategic Management Journal, vol. 18, pp. 509-533, 1997.

[17] M. Augier and D. J. Teece, "Dynamic Capabilities and the Role of Managers in Business Strategy and Economic Performance," Organization Science, vol. 20, pp. 410-421, 2009.

[18] C. L. Wang and P. K. Ahmed, "Dynamic capabilities: A review and research agenda," International journal of management reviews, vol. 9, pp. 31-51, 2007.

[19] M. Tripsas, "Surviving radical technological change through dynamic capability: Evidence from the 
typesetter industry," Industrial and corporate Change, vol. 6, pp. 341-377, 1997.

[20] M. Iansiti and K. B. Clark, "Integration and dynamic capability: evidence from product development in automobiles and mainframe computers," Industrial and corporate change, vol. 3, pp. 557-605, 1994.

[21] A. A. Marcus and M. H. Anderson, "A general dynamic capability: does it propagate business and social competencies in the retail food industry?," Journal of Management Studies, vol. 43, pp. 19-46, 2006.

[22] R. Rasiah, R. B. Shahrivar, and X.-S. Yap, "Institutional support, innovation capabilities and exports: Evidence from the semiconductor industry in Taiwan," Technological Forecasting and Social Change, vol. 109, pp. 69-75, 8// 2016.

[23] L. C. Leonidou, C. N. Leonidou, T. A. Fotiadis, and B. Aykol, "Dynamic capabilities driving an eco-based advantage and performance in global hotel chains: The moderating effect of international strategy," Tourism Management, vol. 50, pp. 268-280, 10// 2015.

[24] M. Lorenzen and L. Frederiksen, "Experimental music: innovation, projects, and dynamic capabilities in the pop music industry," in Working Paper presented at the DRUD PhD Winter Conference, 2003.

[25] M. Sofia and M. Irdayanti, "FOTO: Tutup 31 Desember, Aquarius Mahakam Gelar Diskon Hingga 70\%," in Viva.co.id, ed, 2013.

[26] R. Anderson and S. Syartiqa, "Raksasa Disc Tarra Tutup, Pelanggan Setia Menangis," in Viva.co.id, ed: Viva.co.id, 2016.

[27] A. Zentner, "Online sales, Internet use, file sharing, and the decline of retail music specialty stores," Information Economics and Policy, vol. 20, pp. 288300, 9// 2008.

[28] N. Wlömert and D. Papies, "On-demand streaming services and music industry revenues-Insights from Spotify's market entry," International Journal of Research in Marketing, 2015.

[29] NET. Talent Management. (2015, 6). Rizky Kesempurnaan Cinta [YouTube.com]. Available: https://www.youtube.com/watch?v=XyHhr2XbaGc 